\title{
BRITAIN TO RESHUFFLE ITS PLANT RESEARCH
}

LONDON-Government and industry have set in motion a complicated game of musical chairs for U.K. plant biotechnologists. When the melody stops, there will be two new laboratories in Norwich and another in Cambridge. Moreover, by then the long-promised privatization of the National Seed and Development $\mathrm{Or}$ ganization (NSDO), together with the sale of the plant breeding assets of a major government laboratory, will be complete.

NSDO should finally be sold by this fall, some 18 months after the U.K. government first confirmed its intention to include in the sale part of the Plant Breeding Institute (PBI) of the Agricultural and Food Research Council (AFRC). A price of $\$ 15-50$ million is expected to be paid for PBI's plant breeding research programs, PBI's site and buildings on the outskirts of Cambridge, and what amounts to the ready-made seed company, NSDO

Part of the delay resulted from negotiations with Agricultural Genetics Company Ltd. (AGC, Cambridge, U.K.), which stood to lose some of its recently extended exclusive rights to exploit certain areas of PBI's plant science research. The outcome is that, in exchange for surrendering some of these rights, the company will gain PBI's oilseed rape program and some barley breeding material after privatization.

After its enforced separation from the plant breeding program, PBI's plant science research will move to AFRC's new Institute of Plant Science Research in Norwich. There it will join a molecular plant pathology laboratory, whose establishment was announced in April. Named after its benefactor, supermarket-owner $\mathrm{Da}$ vid Sainsbury, The Sainsbury Laboratory is to receive $\$ 23$ million over 10 years for research on the basis of viral, fungal, and bacterial diseases of plants and the engineering of resistance to them. Precise areas of research will depend on the senior scientific staff, who will be deliberately few in number to allow for a large proportion of research students and visiting scientists. The Sainsbury Lab has been founded "to contribute to a correction" of the erosion of U.K.'s relative strength in molecular plant science. It promises competitive salaries to attract the most able scientists, and resources adequate to allow "research unhampered by inadequate means or seemingly endless administrative difficulties."

A molecular biological approach to plant diseases is also among the research priorities of the grandly titled Centre for Advanced Technology to be built in Cambridge by Twyford International Inc, the parent company of Twyford Plant Laboratories (Glastonbury, U.K.) and Twyford Plant Laboratories Inc. (Santa Paula, CA). Resistance to diseases in potato, cotton, sugar beet, and various other vegetables will be researched, along with work on the genes that determine flower color and the shelf-life of fresh fruit and vegetables. The $\$ 10$ million laboratory will open in Cambridge Science Park next year and employ over 30 scientists under $\mathrm{Mi}$ chael Foxe, a recruit from University

\section{OTA OPINHON POL}

\section{TWO-THIRDS OF AMERICA NOW FAVORS BIOTECH}

WASHINGTON, D.C.-Nearly half the U.S. adults munching on their soon-to-be-engineered cornflakes consider themselves "very interested, concerned, or knowledgeable" about science and technology, according to a new survey conducted by the Congressional Office of Technology Assessment (OTA) in conjunction with Louis Harris \& Associates. Twothirds of those polled think that genetic engineering "will make life better for all people." And, although public support is high for human gene therapy, just over half of those queried believe that genetically engineered products are "somewhat likely" to be dangerous to people or the environment, with a majority thinking that "strict regulation" is essential

OTA conducted the public opinion survey as part of its continuing assessment, "New Developments in Biotechnology." More than 1,200 adults were polled during a 19-day period last autumn. They were asked about science and technology issues in general, and genetic engineering and biotechnology in particular. The findings contrast in several ways with those of a similar survey, conducted in 1985 by Jon $D$. Miller of Northern Illinois University (DeKalb). The earlier survey indicated lower awareness of biotechnology among religious, environmental, and science policy leaders-but similar high expectations for its promised benefits.

If awareness of biotechnology seems to have grown in recent months, so also has the public's ap-
College (Dublin). By moving its molecular biologists from Glastonbury to Cambridge and adding to their number, Twyford hopes to increase its exploitation of academic discoveries.

It is, perhaps, ironic that Twyford's molecular biologists should be migrating to Cambridge just as PBI's researchers begin to contemplate the move from Cambridge to Norwich (or elsewhere, as in the case of the director Peter Day, who is decamping to the United States). Although there is widespread criticism of the separation of the science research from the breeding programs of $\mathrm{PBI}$ that will be forced by privatization, there may be a net gain for U.K. plant sciences as a whole

-Peter Newmark

parent willingness to accept some risks. "If there were no direct risk to humans and very remote risks to the environment, a majority of the public" would approve applications of genetically engineered organisms involving deliberate release, the OTA survey finds. Although most of those polled favor small-scale tests, however, only 42 percent would now go along with large-scale uses

Even though the majority of U.S adults seems keen on genetic engineering, a small group voices strong objections. According to OTA, onethird of Americans think we would be "better off" if we did not know how to alter cells genetically. A smaller group, 11 percent, disapproves of manipulating human cells, even to cure fatal diseases. Moreover, 18 percent would not approve a deliberate release, even if the environmental risk was "one in a million."

The OTA survey has won high marks from several members of Congress, whom it is intended to serve. Representative Robert Roe (D-NJ) who chairs the House Committee on Science, Space, and Technology, calls the report "valuable," noting that it will help the committee examine issues affecting the biotechnology in dustry. Committee member Manue Lujan Jr. (R-NM) adds that the survey "lends public support" to the committee's efforts, noting: "Biotechnology is an extraordinarily beneficial, potentially billion-dollar technology that we don't want to regulate out of business."

-Jeffrey L. Fox 